\title{
Free Fatty Acid Concentration and Carboxymethylcellulase Activity of Some Formulas of Protected Fat-proteins Tested In Vitro
}

\author{
Lilis Hartati ${ }^{1)^{*}}$, Ali Agus ${ }^{2)}$, Lies Mira Yusiati ${ }^{2)}$ and Budi Prasetyo Widyobroto ${ }^{2)}$ \\ 1)Faculty of Agriculture, Lambung Mangkurat University, Jl. A. Yani km 36, Banjarbaru, \\ South Kalimantan, 70714, Indonesia \\ 2)Faculty of Animal Science, Gadjah Mada University, JI. Fauna 3, Bulaksumur, Yogyakarta 55281, Indonesia \\ *Corresponding author email: lilishartati_gk@yahoo.co.id
}

\begin{abstract}
The aim of this study was to determine the levels of free fatty acids and carboxymethylcellulase activity (cmc-ase) activity of some protected fat-proteins base on in vitro Tilley and Terry method. Two sources of fat, i.e. crude palm oil and fish oil and three sources of protein i.e. skim milk, soybean flour and soybean meal were used in the formulation of protected fat-protein, and thus there were six treatment combinations. The filtrate from the in vitro test was analyzed for the levels of free fatty acids and cmcase activity. The result of this research indicates that different combinations of feed materials and fat give different content of free fatty acid in first stage and second stage in vitro, with the best results in the combination treatment of skim milk and palm oil that give the lowest result of free fatty acid concentration in fisrt stage in vitro $(0.168 \%)$ and the highest result free fatty acid concentration in second stage in vitro $(4.312 \%)$. The activity of CMC-ase was not influenced by different sources of fat and protein. It can be concluded was that the protection of the combination between skim milk and CPO gives the highest protection results.
\end{abstract}

Key words: enzyme activity, free fatty acid, in vitro, protected fat-protein

Abstrak. Penelitian ini bertujuan untuk mengetahui kadar asam lemak bebas dan aktivitas $\mathrm{cmc}$-ase beberapa protein lemak terproteksi secara in vitro metode Tilley and Terry. Dua sumber lemak yaitu minyak sawit mentah dan minyak ikan serta tiga sumber protein yaitu susu skim, tepung kedelai dan bungkil kedelai digunakan sebagai bahan untuk membuat protein lemak terproteksi, sehingga terdapat 6 kombinasi perlakuan. Filtrat dari uji in vitro di analisis kadar asam lemak bebasnya dan aktivitas enzim cmcasenya. Dari hasil penelitian ini diperoleh bahwa perbedaan kombinasi sumber protein dan sumber minyak memberikan kadar asam lemak bebas yang berbeda pada in vitro tingkat 1 dan tingkat 2 dengan hasil terbaik pada perlakuan kombinasi susu skim dan CPO yang memberikan hasil kadar asam lemak bebas terendah sebesar $0,168 \%$ pada in vitro tingkat 1 dan kadar asam lemak bebas tertinggi sebesar 4,312\% pada in vitro tingkat 2 . Aktivitas $\mathrm{cmc}$-ase tidak mengalami perbedaan dengan adanya perbedaan sumber minyak dan sumber protein. Kesimpulan dari penelitian ini adalah bahwa kombinasi susu skim dan minyak sawit mentah memberikan hasil proteksi yang terbaik dilihat dari kadar asam lemak bebas pada in vitro tingkat 1 dan tingkat 2 .

Kata kunci: aktivitas enzim, asam lemak bebas, in vitro, protein lemak terproteksi

\section{Introduction}

Fat is the most potential and cheapest source of energy and the precursor of milk unsaturated fatty acids synthesis. However, the inclusion of fat in the ruminant ration is very restricted. It is because the use of fat more than $5 \%$ in the ration will negatively affect rumen microbe ecosystem and decrease crude fiber digestibility. Fat ration that enters the rumen will undergo hydrolysis and fatty acids undergo hydrogenation. Free fatty acids in the rumen tends to stick to the feed particles and microbes that affect the fermentation of carbohydrate mainly structural carbohydrate fermentation (Wattiaux and Grummer, 1995)

The using of fat in the diet of ruminants is still limited, ie a maximum of $5 \%$ of dry matter because it will inhibit rumen microbial activity in degrading fiber (Doreau and Chilliard, 1996; Palmquist et al., 1993). The use of protected fat does not interfere with the fermentation process of raw fiber in the rumen (Bayourthe et al., 1994; Bayourthe et al., 1993) and it can be a 
source of energy (Wettstein et al., 2001) that does not negatively affect digestibility of structural carbohydrates; it can be seen from the activity of cellulase enzymes in the rumen. In addition, the unsaturated fatty acids reaching in the intestine can increase the levels of long chain unsaturated fatty acid (polyunsaturated fatty acids) milk (Gulati et al., 2005).

Crude palm oil and fish oil contain high level of poly unsaturated fatty acid (PUFA) (Gurr, 1984; Saify et al., 2003). Methods of protection through the encapsulation with the protein matrix, that has been protected with formaldehyde,_capable of providing adequate protection is high (82-86\%) and does not significantly affect the digestibility of carbohydrates (Sklan, 1989; Sklan and Tinsky, 1993).

This research data was part of a series of studies aimed to evaluate the protected fat against an increasing of unsaturated fatty acids of milk, and at this point, be done evaluate using in vitro technique to measure effectiveness of protection in the rumen digestion.

\section{Materials and Method}

Three protein sources and two fat sources were used in this research. The sources of protein were skim milk, soy flour, and soybean meal. The sources of fat were crude palm oil (CPO) and fish oil. The procedure in the capsulation of fat with protein matrix was based on the method from our previous research i.e. such amount of fat and protein (1:3) was homogeny mixed and then sprayed with formaldehyde $(37 \%$ of formaldehyde solution) in amount to find the final dosage of formaldehyde in the mixture was $1.5 \%$.

Finally, there were 6 combinations of protected fat-protein which were evaluated its degradability using modified Tilley and Terry in vitro technique, namely: T1 (skim milk and CPO); T2 (skim milk and fish oil); T3 (soy flour and CPO); T4 (soy flour and fish oil); T5 (soybean meal and CPO); and T6 (soybean meal and fish oil).

All of six combinations were tested for its effectivity protection in vitro, by using the method of Tilley and Terry (1963) with 3 replications. In order to compare rumen digestibility and post rumen digestibility, two groups of protected fat-protein were prepared, those were (1) one stage in vitro Tilley and Terry Method and (2) two stage in vitro Tilley and Terry Method. After 48 hours of incubation (for one stage) or 96 hours of incubation (for two stage) the in vitro solution was filtered out from fermentation tube and then the filtrate was tested to determine the levels of free fatty acids. Its effect on rumen microbial enzyme activity was observed by testing the CMC-ase. The filtrate from one stage in vitro was centrifuged at 10,000 rpm for 5 minutes and then tested in the cmcase activity.

Determination of free fatty acids (FFA) used titration methode of Mehlenbacher (1960) in Sudarmadji et al. (1984) as follow: sample was mixed and be in a liquid state at a time sampled. The sample is weighed as much as $28.2 \pm 0.2 \mathrm{~g}$ inclusion in Erlenmeyer. Added 50 $\mathrm{ml}$ of hot neutral alcohol and $2 \mathrm{ml}$ indicator PP (Phenolphthalein). Then titrated with a $0.1 \mathrm{~N}$ $\mathrm{NaOH}$ that has been standardized, until the pink color is achieved, and does not disappear for $30 \mathrm{sec}$. Percent free fatty acid expressed as oleic on most oils and fats. For palm oil and palm kernel oil is declared as lauric, while palm oil is expressed as palmitate. Free fatty acids was expressed as \% FFA.

\% FFA $=(\mathrm{mL} \mathrm{NaOH} \times \mathrm{N} \times$ molecular weight of fatty acids $\times 100$ ) /(weight of sample $\times 1000$ )

The assay for the cmcase activity using methods Halliwel et al. (1985) modified, based on the release of glucose that was detected using potassium ferricyanide. The cmcase analysis was performed as follow: 
Table 1. CMSase analysis

\begin{tabular}{lccccc}
\hline \multicolumn{1}{c}{ Tube } & Enzyme $(\mathrm{ml})$ & $\begin{array}{c}\text { Buffer Na acetate } \\
\mathrm{pH} 5.5(\mathrm{ml})\end{array}$ & $\mathrm{CMC} 1 \%(\mathrm{ml})$ & $\mathrm{H}_{2} \mathrm{O}(\mathrm{ml})$ & Total $(\mathrm{ml})$ \\
\hline Enzyme+substrate & 0.1 & 0.4 & 1 & 0.3 & 1.8 \\
Enzyme & 0.1 & 0.4 & - & 1.3 & 1.8 \\
Substrate & - & 0.4 & 1 & 0.4 & 1.8 \\
Blank & - & 0.4 & - & 1.8 & 1.8 \\
\hline
\end{tabular}

All the tubes were incubated in waterbath at $38^{\circ} \mathrm{C}$ for 45 minutes. The enzyme activity was stopped by the addition of $3.2 \mathrm{ml}(1 \mathrm{ml}$ cyanide carbonate $+0.2 \mathrm{ml}$ of sodium carbonate $+2 \mathrm{ml}$ $0.05 \%$ potassium ferricyanide $\mathrm{pH} 10.6)$. The solution in the test tubes were homogenized, and heated in a waterbath at $100^{\circ} \mathrm{C}$ for 30 minutes, after cold, was read using $\lambda$ Spectrophotometer at $420 \mathrm{~nm}$. Absorbance product $=$ abs $(B L-E S)-(B L-E)-(B L-S)$. Content of glucose obtained using a standard curve of glucose by spectrophotometry that optimum at $\lambda 540 \mathrm{~nm}$.

One unit of enzyme activity was defined as the amount of enzyme that produces $1 \mu \mathrm{mol}$ glucose per minute under the condition analysis. The specific activity is an activity unit per $\mathrm{mg}$ protein enzyme. Concentration of enzyme protein was measured by method of Lowry (Plummer, 1987). Content of protein solution was determined from a standard curve of bovine serum albumin (BSA).

Data were analyzed using a completely randomized design variance and if there was a difference, it would be continued by Duncan's Multiple Range Test (DMRT).

\section{Results and Discussion}

\section{Free fatty acid concentration}

The results of measurement for free fatty acid concentration on fisrt stage invitro provides the lowest results on a combination of skim milk-CPO (0.168\%) and the highest value on a combination of soy flour-fish oil $(0.232 \%)$. By this protection, expected levels of free fatty acids in fisrt stage of the in vitro was low. In the in vitro second stage, free fatty acid concentration have the highest value on combination of skim milk-cpo (4.132\%) and the lowest value on combination of soybean mealсро (3.512\%). In the second stage in vitro was expected to have high free fatty acid content, that will facilitate subsequent absorption in the gastrointestinal tract.

Results of other studies wrote, that differences in levels of formaldehyde of 1.0; 1.5 and $2.0 \%$ did not give significantly different result on free fatty acid concentration in the second stage in vitro, but on the second stage in vitro had a value of free fatty acid concentration higher than free fatty acid concentration at the first stage in vitro (Hartati, 2014).

The protection of proteins and fats using formaldehyde will cause the formation of crosslinks between the protein and aldehyde so that the fat will be trapped in the matrix which was insoluble and resistant to rumen microbial degradation (Ashes et al., 1995; Kiernan, 2000), so that the free fatty acid concentration in the first stage in vitro was low.

Evaluation of some protected fat-protein also showed, that in vitro digestibility of fat had low value at fisrt stage, but had a high value at second stage in vitro (Hartati et al., 2012a).

Table 2 also showed that the protection method was used quite effectively on all combinations of feed ingredients with low levels of free fatty acid at fist stage and became a high free fatty acid content at second stage.

\section{CMC-ase activity}

The results CMC-ase (Carboxy Methyl cellulase activity test of fluid in vitro were presented in Table 3. CMC-ase activity was 
Table 2. Average concentration of free fatty acids of filtrate at fisrt stage and second stage in vitro of six combination of protected fat-protein (\%)

\begin{tabular}{lcccccc}
\hline Incubation & \multicolumn{5}{c}{ Treatment } \\
\cline { 2 - 7 } stage & $\mathrm{T} 1$ & $\mathrm{~T} 2$ & $\mathrm{~T} 3$ & $\mathrm{~T} 4$ & $\mathrm{~T} 5$ & $\mathrm{~T} 6$ \\
\hline First stage & $0.168^{\mathrm{b}}$ & $0.168^{\mathrm{b}}$ & $0.181^{\mathrm{ab}}$ & $0.232^{\mathrm{a}}$ & $0.194^{\mathrm{ab}}$ & $0.194^{\mathrm{ab}}$ \\
Second stage & $4.312^{\mathrm{a}}$ & $4.117^{\mathrm{ab}}$ & $3.798^{\mathrm{bc}}$ & $3.837^{\mathrm{bc}}$ & $3.512^{\mathrm{c}}$ & $3.636^{\mathrm{c}}$
\end{tabular}

a,b Values bearing different superscripts within row are significantly different $(P<0.05)$

T1 (skim milk and CPO); T2 (skim milk and fish oil); T3 (soy flour and CPO); T4 (soy flour and fish oil); T5 (soybean meal and CPO); and T6 (soybean meal and fish oil).

Table 3. The average of specific activity of CMC-ase from the filtrate in vitro six combination of fat protein protected ( $\mathrm{mol} / \mathrm{mgprot} / \mathrm{min}$ )

\begin{tabular}{lcccccc}
\hline & \multicolumn{7}{c}{ Treatment } \\
\cline { 2 - 7 } & T1 & T2 & T3 & T4 & T5 & T6 \\
\hline $\begin{array}{l}\text { Specific activity } \\
\text { ( } \mu \mathrm{mol} / \text { mgprot/minute) }^{\text {ns }}\end{array}$ & 0.0570 & 0.0578 & 0.0410 & 0.0450 & 0.0275 & 0.0302
\end{tabular}

T1 (skim milk and CPO); T2 (skim milk and fish oil); T3 (soy flour and CPO); T4 (soy flour and fish oil); T5 (soybean meal and $\mathrm{CPO}$ ); and T6 (soybean meal and fish oil). ns Non significant

tested to represent the ability to degrade raw fiber for cellulolytic bacteria rumen fluid.

Outcome of this study was lower than the results of other studies of culture, that there is no effect of formaldehyde as a feed protection agency, such as the results of Purwadaria et al. (2003) that the culture of the bacteria have $\mathrm{cmc}$-ase activity of $1.00 \mathrm{U} / \mathrm{mg}$ protein.

The use of fats protected for ruminant proven not affect digestibility of crude fiber (Haddad and Younis, 2004; Hartati et al., 2012b; Cortes et al., 2010), this proves that the ability to degrade cellulose by cellulase enzymes was not affected.

Table 3 showed that the protection of proteins and fats using formaldehyde from various sources of feed materials did not give different results in the ability to degrade the fiber. It can be interpreted that the protection method used did not affect the activity of cellulolytic microbes to degrade raw fiber.

\section{Conclusions}

It can be concluded that the different combinations of feed materials and oil give different content of free fatty acid in firts stage and second stage in vitro, with the best results in the combination treatment of skim milk and palm oil that give the lowest result of free fatty acid in fisrt stage in vitro $(0.168 \%)$ and the highest result free fatty acids in second stage in vitro (4.312\%). The activity of CMC-ase was not influenced by different sources of oil and protein. The protection of the combination between skim milk and CPO gives the highest protection results.

\section{Acknowledgement}

This researh was funded by DGHE of National Education Ministry.

\section{References}

Ashes JR, E Fleck and TW Scott. 1995. Dietary manipulation of membran lipids and its implications for their role in the production of second messengers. In: Ruminant Physiology: Digestion, Metabolism, Growth and Reproduction. Edited by W. v. Engelhardt, S. Leonhard-Marek, G. Breves and D. Giesecke. Ferdinand Enke Verlag. Stuttgart.

Bayourthe C, M Vernay and R Moncoulon. 1994. Effect of calsium salts of fatty acids on rumen function and the digestibility of ration by sheep. J. Sci.Food. Agric. 64: 341-347.

Bayourthe C, R Moncoulon and M Vernay. 1993. Effect of protein -protected fat on ruminal and total nutrient digestibility of sheep diets. J Anim. Sci 71:1026-1031 
Cortes C, DC da Silva-Kazama, R Kazama, N Gagnon, C Benchaar, GTD Santos, LM Zeoula and HV Petit. 2010. Milk composition, milk fatty acid profile, digestion, and ruminal fermentation in dairy cows fed whole flaxseed and calcium salts of flaxseed oil. J. Dairy Sci. 93:3146-3157.

Doreau $M$ and $Y$ Chilliard. 1996. Digestion and metabolism of dietary fat in farm animal. In: An International Conference on Fats in The Diets of Animal and Man. Birmingham.

Gulati SK, MR Garg and TW Scott. 2005. Rumen protected protein and fat produced from oilseeds and/or meals by formaldehyde treatment; their role in ruminant production and product quality: a review. Australian Journal of Experimental Agriculture. 45:1189-1203.

Gurr MI. 1984. The chemistry and biochemistry of plant fats and their nutritional importance. In: Fats in Animal Nutrition. Edited by J. Wiseman. Butterworths. London.

Haddad SG and HM Younis. 2004. The effect of adding ruminally protected fat in fattening diets on nutrient intake, digestibility and growth performance of Awassi lamb. Anim. Feed Sci. Tech. 113:61-69.

Halliwel G, MNBA Wahab, AH Patel. 1985. Chemical composition of endo-1,4-ß-D-glucanases to cellulotic in Trichoderma koningii. J. Appl. Biochem. 7:43-45.

Hartati L. 2014. Upaya Peningkatan Asam Lemak Susu Sapi Perah Dengan Suplementasi Lemak Terproteksi. Dissertation. Gadjah Mada University. Yogyakarta.

Hartati L, A Agus, BP Widyobroto and LM Yusiati. 2012a. In Vitro Digestibilities of Six Rumen Protected Fat-Protein Supplement Formulas. Animal Production 14 (1):1-5.

Hartati L, A Agus, LM Yusiati and BP Widyobroto. 2012b. Inclusions of Rumen Protected ProteinFat Supplements in the Ration of Lactating Dairy Cow: Effects on Feed Intake and Digestibility, Milk Production and Composition, and Milk Fatty Acid Profile. Proceeding the $15^{\text {th }}$ AAAP animal Science Congress "Improving Smallholder and Industrial Livestock Production for Enhancing
Food Security, Environment and Human Welfare" , 26-30 Nopember, Bangkok, Thailand.

Kiernan JA. 2000. Formaldehyde, formalin, paraformaldehyde and glutaraldehyde: What they are and what they do. Microscopy Today 00-1:8-12.

Palmquist DL, MR Weisbjerg and T Hvelplund. 1993. Ruminal, intestinal and total digestibilities of nutrients in cows fed diets high in fat and undegradable protein. J. Dairy Sci. 76: 13531364.

Plummer DT. 1971. An Introduction to Practical Biochemistry. Tata McGraw-Hill Publishing Company Ltd. UK.

Purwadaria T, PA Marbun, AP Sinurat dan PP Ketaren. 2003. Perbandingan Aktivitas Enzim Selulase dari Bakteri dan Kapang Hasil Isolasi dari Rayap. JITV Vol. 8 No. 4:213-219.

Saify ZS, S Akhtar, KM Khan, S Perveen, SAM Ayattollahi, S Hassan, M Arif, SM Haider, $F$ Ahmad, S Siddiqui and MZ Khan. 2003. A Study on the fatty acid composition of fish liver oil from two marine fish, Euspyra blochii and Carcharhinus bleekeri. Turkey J. Chemistry. 27:251-258.

Sklan D and M Tinsky, 1993. Production and reproduction response by dairy cows fed varying undegradable protein coated with rumen bypass fat. J. Dairy Sci. 76:216-223.

Sklan D. 1989. In vitro and in vivo protection of protein coated with calcium soaps of long fatty acid in ruminants. J. Agric. Sci. (Camb) 112:79-86.

Sudarmadji S, B Haryono dan Suhardi. 1984. Prosedur Analisis untuk Bahan Makanan dan Pertanian. $3^{\text {th }}$ Edition. Liberty. Yogyakarta.

Tilley JMA and R A Terry. 1963. A two stage technique for in vitro digestion of forage crop. Journal of the British Grassland Society 18: 104111.

Wettstein HR, MRL Scheeder, F Sutter and M Kreuzer. 2001. Effect of lecithins partly replacing rumen-protected fat on fatty acid digestion and composition of cow milk. Eur. J.Lipid Sci. Tecnol. 103:12-22. 